\title{
DETERMINAN EFISIENSI TEKNIS USAHA MIKRO KECIL (UMK) MENGGUNAKAN PENDEKATAN STOCHASTIC FRONTIER ANALYSIS DI PROVINSI BANTEN
}

\author{
Saeful Hidayat*1, Sadi'ah ${ }^{2}$ \\ 1,2 BPS Provinsi Banten \\ saefulh@bps.go.id*1, sadiah@bps.go.id ${ }^{2}$
}

\begin{abstract}
Micro and Small Enterprises (MSEs) play an important role in Banten's economy. MSEs are also a very strong and resilient business sector and have the potential to continue to grow continuously. The development of MSEs needs to be driven by increased income and business efficienscy. The question is whether the opportunity to increase the income and technical efficiency of MSEs is still open enough? This study aims to evaluate the level of technical efficiency that has been achieved by MSEs and the factors that affect the level of efficiency. Using the SFA-TE Effect Model, the results showed that the average level of efficiency achieved by MSEs was 0.901, with a coefficient of variation of 0.08. The main factors affecting the level of achievement of technical efficiency are the internet use, business location, and business partnerships. However, factors that have implications for government policy are internet use, business partnerships, and access to capital from formal financial institutions. The use of internet use is also a new finding in research on the determinants of MSEs efficiency
\end{abstract}

Keyword: technical efficiency, TE Effect Model, Micro and Small Enterprises

\begin{abstract}
Abstrak
UMK memegang peran penting dalam perekonomian Banten. UMK juga menjadi sektor usaha yang sangat kuat dan tahan banting, serta sangat berpotensi untuk terus berkembang. Pengembangan UMK perlu didorong oleh peningkatan pendapatan dan efisiensi usaha. Pertanyaannya adalah apakah kesempatan untuk meningkatkan pendapatan dan efisiensi teknis UMK masih cukup terbuka? Penelitian ini ditujukan untuk mengevaluasi tingkat efisiensi teknis yang telah dicapai oleh UMK dan faktor-faktor yang mempengaruhi tingkat efisiensinya. Menggunakan SFA-TE Effect Model, hasil penelitian menunjukkan bahwa rata-rata tingkat efisiensi yang dicapai UMK adalah 0,901, dengan koefisien variasi 0,08 . Faktorfaktor utama yang mempengaruhi tingkat pencapaian efisiensi teknis tersebut adalah penggunaan internet, lokasi usaha dan kemitraan usaha. Namun yang berimplikasi kepada kebijakan pemerintah adalah penggunaan internet, kemitraan usaha dan akses modal. Penggunaan internet ini juga menjadi temuan baru dalam penelitian mengenai deteminan efisiensi UMK.
\end{abstract}

Kata kunci: efisiensi teknis, TE Effect Model, usaha mikro kecil 


\section{PENDAHULUAN}

Usaha mikro dan kecil (UMK) merupakan salah satu sektor usaha yang banyak dijalankan oleh masyarakat umum, sehingga mendominasi dunia usaha di Indonesia, termasuk Banten. Berdasarkan hasil Sensus Ekonomi 2016 Lanjutan (SE2016-Lanjutan), jumlah usaha UMK mencapai 944 ribu unit usaha atau 97,9 persen dari total usaha non pertanian Banten. UMK menyebar di seluruh kabupaten/kota, dengan lebih dari separuhnya berada di wilayah Tangerang Raya. Adapun jenis usahanya, terkonsentrasi pada sektor atau lapangan usaha perdagangan besar-eceran dan reparasi mobil-sepeda motor (49,5 persen), penyediaan akomodasi dan makan minum (19,3 persen), serta industri pengolahan (10,2 persen) (BPS Provinsi Banten, 2019).

UMK menjadi sumber penghidupan masyarakat banyak. Jumlah tenaga kerjanya sebanyak 1,98 juta orang atau sekitar 59,2 persen dari jumlah tenaga kerja non pertanian Banten. Seperti halnya jumlah usaha, lebih dari separuh pekerja UMK berada di wilayah Tangerang Raya. Pekerja UMK juga terkonsentrasi pada lapangan usaha perdagangan besareceran dan reparasi/perawatan mobil-sepeda motor (43,2 persen), penyediaan akomodasi dan makan minum (16,7 persen), serta industri pengolahan (12,7 persen) (BPS Provinsi Banten, 2019).

Dengan demikian, UMK memegang peran penting dalam perekonomian Banten. Khususnya, dalam menggerakkan roda perekonomian masyarakat, menurunkan angka pengangguran, mengentaskan masyarakat dari jurang kemiskinan, dan mengurangi ketimpangan pendapatan antar penduduk.Adapun kontribusinya dalam pembentukan PDRB Banten masih sangat rendah, yakni kurang dari seperempatnya (BPS Provinsi Banten, 2019).

Selain memiliki peran penting, UMK juga menjadi sektor usaha yang sangat kuat dan tahan banting. Pada saat krisis ekonomi dan moneter melanda Indonesia di tahun 1997-1998, UMK bersama usaha menengah (gabungan keduanya disingkat menjadi UMKM) terbukti mampu bertahan. Pada saat krisis itu, korporasi swasta atau usaha besar (UB) banyak yang berguguran, sedangkan UMKM justru banyak yang tumbuh dan berkembang.

Sayangnya pada masa pandemi Covid-19 ini, UMK juga menjadi kelompok usaha yang rentan. Data BPS Provinsi Banten menyebutkan bahwa 87 persen UMK mengalami penurunan pendapatan karena terdampak Covid-19. Imbasnya, sekitar 74 persen UMK menghadapi kendala keuangan terkait pembayaran upah/gaji dan operasional perusahaan. Malahan, terdapat 43 persen UMK yang melakukan pengurangan pekerja (BPS Provinsi Banten, 2020a).

Betapapun juga, UMK tetap menjadi tumpuan harapan masyarakat banyak dan sangat 
Jurnal Lebesgue : Jurnal Ilmiah Pendidikan Matematika, Matematika dan Statistika

Saeful Hidayat, Sadi'ah

Volume 2, No. 1, April 2021 hal.45-61

DOI Artikel : 10.46306/lb.v2i1.55

berpotensi untuk terus berkembang. Kondisi tersebut dapat diketahui dari meningkatnya jumlah UMK di Banten selama periode Agustus 2019-Agustus 2020. Dalam hal ini, ditandai oleh bertambahnya jumlah penduduk yang berusaha sendiri dan yang berusaha dibantu buruh tidak tetap/buruh tidak dibayar, masing-masing sebanyak 120 ribu orang dan 59 ribu orang (BPS Provinsi Banten, 2020b).

Pengembangan UMK ini perlu didorong oleh peningkatan daya saing dan kinerja usaha. Ada dua hal yang harus dilakukan pelaku UMK untuk meningkatkan kinerja dan daya saing usaha, yaitu efektivitas dan efisiensi usaha. Efektivitas merupakan kemampuan untuk memilih tujuan yang tepat atau peralatan yang tepat untuk pencapaian tujuan yang telah ditetapkan. Dengan kata lain, efektivitas adalah memilih pekerjaan yang harus dilakukan atau metode yang tepat untuk mencapai tujuan (Fariz, 2017). Dalam konteks UMK, efektivitas adalah menjual atau memproduksi barang/jasa berkualitas, yang sesuai dengan permintaan masyarakat.

Adapun efisiensi merupakan kemampuan untuk menyelesaikan suatu pekerjaan dengan benar. Dalam arti, mencapai output atau keluaran yang lebih tinggi (hasil, produktivitas, performance) dibandingkan input atau masukan (tenaga kerja, bahan, uang, mesin, dan waktu) yang digunakan. Dengan kata lain, efisiensi adalah meminimumkan biaya penggunaan sumber daya-sumber daya untuk mencapai keluaran yang telah ditentukan, atau memaksimumkan keluaran dengan jumlah masukan yang terbatas (Fariz, 2017; Farrel, 1957; Aigner dkk, 1977; Charness dkk, 1978).

Penelitian ini akan memusatkan diri pada masalah efisisiensi UMK. Pertimbangannya, UMK pada masa pandemi Covid-19 oleh pemerintah daerah masih dijadikan salah satu penopang pertumbuhan ekonomi dan perkembangan wilayah. Oleh karena itu, pengembangan UMK perlu didukung dengan kajian yang cukup komprehensif terkait peningkatan kinerja usaha UMK.

Penelitian efisisiensi UMK ini mengandung dua tujuan. Pertama, melakukan evaluasi secara komperehensif terhadap tingkat efisiensi teknis (TE) UMK dalam seluruh kategori lapangan usaha non pertanian di Provinsi Banten. Kedua, menyelediki determinan atau faktorfaktor yang menentukan atau mempengaruhi TE UMK non pertanian di Banten.

Data dan informasi yang dihasilkan dari penelitian ini sangat bermanfaat bagi pemerintah daerah. Data TE yang dihasilkan, dapat dijadikan tolok ukur capaian program pengembangan UMK yang telah dilaksanakan. Adapun informasi terkait determinan efisensi usaha, bisa digunakan sebagai bahan perencanaan pembangunan UMK di masa depan. Oleh karena itu, hasil penelitian ini diharapkan dapat menjadi rujukan pemerintah daerah dalam menyusun 
Jurnal Lebesgue : Jurnal IImiah Pendidikan Matematika, Matematika dan Statistika

Saeful Hidayat, Sadi'ah

Volume 2, No. 1, April 2021 hal.45-61

DOI Artikel : 10.46306/lb.v2i1.55

kebijakan guna meningkatkan daya saing dan kinerja UMK, sekaligus mengembangkan perekonomian daerah.

\section{METODE PENELITIAN}

Pengukuran efisiensi teknis, khususnya terkait dengan fungsi produksi frontier (FPF), telah lama dibahas oleh Farrell (1957). FPF ini merupakan fungsi yang menggambarkan tingkat produksi maksimum yang dapat dihasilkan dari sejumlah masukan dalam suatu proses produksi. Adapun pengukuran tingkat efisiensi teknis (TE), dilakukan dengan membandingkan fungsi produksi aktual dari suatu jenis usaha, terhadap fungsi produksi frontier yang merupakan fungsi produksi potensial dari jenis usaha tersebut.

Ada dua metode yang umum digunakan untuk menghitung tingkat efisiensi teknis (TE), yaitu data envelopment analysis (DEA) dan stochastic frontier analisys (SFA). DEA merupakan metode non parametrik, yang memanfaatkan linear programming untuk membangun FPF. DEA tidak membutuhkan asumsi mengenai bentuk fungsi produksi. Fungsi produksi terbaik dibuat secara empiris dari input dan output hasil amatan (Coelli, 1996a). DEA juga tidak mampu memisahkan kesalahan acak (random error) dengan inefisiensi teknis (Kontodimopoulos dkk. 2010; Coelli dkk., 2005).

Adapun SFA adalah metode parametrik, dimana bentuk dari fungsi produksinya diasumsikan diketahui atau diestimasi secara statistik. Dalam SFA, hubungan antara input dan output mengikuti bentuk fungsi produksi yang sudah diketahui atau diestimasi tersebut. SFA juga memungkinkan parameter lain dari teknologi produksi untuk dieksplorasi (Coelli 1996b; Coelli dkk. 2005). SFA, secara simultan dapat mengestimasi efisiensi teknis dan model efek inefisiensi teknis. Estimasi secara simultan ini dikenal sebagai TE Effect Model, yang dikembangkan oleh Battese dan Coelli (1995).

Dengan mempertimbangkan tujuan penelitian dan keunggulan yang melekat pada metode SFA, penelitian ini menggunakan metode SFA-TE Effect Model. Bentuk model stochastic production frontier (SPF) yang digunakan secara umum mengikuti fungsi produksi CobbDouglas untuk data silang (cross-sectional data) yang diberikan oleh Kumbhakar dan Lovell (2000). Adapun spesifikasi modelnya adalah sebagai berikut:

$$
\ln y_{i}=\beta_{0}+\sum_{k=1}^{3} \beta_{k} \operatorname{In} x_{k i}+\left(v_{i}-u_{i}\right)
$$

dimana,

$i=$ UMK ke-i 
Jurnal Lebesgue : Jurnal IImiah Pendidikan Matematika, Matematika dan Statistika

Saeful Hidayat, Sadi'ah

Volume 2, No. 1, April 2021 hal.45-61

Dol Artikel : 10.46306/lb.v2i1.55

$y_{i}=$ Pendapatan usaha sebulan (rupiah)

$x_{l i}=\quad$ Biaya produksi (pengeluaran usaha non upah/gaji pekerja) sebulan (rupiah)

$x_{2 i}=$ Tenaga kerja (orang)

$\mathrm{x}_{3 \mathrm{i}}=$ Jam kerja per hari (jam)

$\beta_{0}, \beta_{1}, \beta_{2}, \beta_{3}=$ Parameter fungsi produksi

$v_{\mathrm{i}}=$ variabel acak (random error) yang berdistribusi normal dengan nilai rata-rata nol dan varian $\sigma_{v}{ }^{2}$.

Sementara $u_{i}$ adalah fungsi inefisiensi teknik (technical inefisiency). Untuk melakukan estimasi fungsi inefisiensi teknis, dalam penelitian ini digunakan delapan variabel penjelas yang diasumsikan mempengaruhi inefisiensi teknis UMK. Kedelapan variabel penjelas tersebut dan hubungannya dengan inefisiensi teknik, digambarkan dalam persamaan berikut:

$u_{i}=\lambda_{0}+\sum_{j=1}^{8} \lambda_{j} \operatorname{In} z_{j_{i}}+\varepsilon_{i}$

dimana,

$z_{l i}=$ pendidikan (pendidikan pengusaha)

$($ Tidak Tamat SD $=1, \mathrm{SD}$ dan Sederajat $=2, \mathrm{SMP}$ dan Sederajat $=3$, SMA dan Sederajat $=$ 4 ,

Diploma I/II/III = 5, Diploma IV/S1 = 6, dan S2/S3 = 7)

$z_{2 i}=$ lokasi $($ Lokasi usaha di perkotaan $=1 ;$ Lokasi usaha di perdesaan $=0$ )

$z_{3 i}=$ lama usaha (tahun)

$z 4 i=$ akses modal (Memiliki akses permodalan dari lembaga keuangan formal $=1$;

Tidak Memiliki akses permodalan dari lembaga keuangan formal =0)

$z_{5 i}=$ kemitraan (Menjalin kemitraan dengan usaha/perusahaan lain $=1$;

Tidak menjalin kemitraan dengan usaha/perusahaan lain $=0$ )

$z_{6 i}=$ internet $($ Menggunakan internet untuk pemasaran dan transaksi penjualan $/$ pembelian $=1$;

$$
\text { Lainnya }=0 \text { ) }
$$

$z_{7 i}=$ infrastruktur (Tidak terkendala infrastruktur (jalan, air, komunikasi, dll) $=1$;

Terkendala infrastruktur (jalan, air, komunikasi, dll) =0)

$\lambda_{0}, \lambda_{1}, \lambda_{2}, \ldots, \lambda_{9}=$ Parameter Inefisiensi 
Jurnal Lebesgue : Jurnal IImiah Pendidikan Matematika, Matematika dan Statistika

Saeful Hidayat, Sadi'ah

Volume 2, No. 1, April 2021 hal.45-61

DOI Artikel : 10.46306/lb.v2i1.55

$\varepsilon_{\mathrm{i}}=$ variabel acak non negatif yang berdistribusi normal (non-negatif truncations of the normal distributions) dengan rata-rata $\mu$ dan varian $\sigma_{v}{ }^{2}$.

Nilai dari parameter pada persamaan (1) dan (2) diestimasi secara simultan melalui metode Maximum Likelihood (MLE), dengan menggunakan package frontier yang ada pada program komputasi Stata/SE 12.0 for Windows.

Sementara TE yang dihasilkan, dihitung mengikuti persamaan berikut :

$$
\begin{aligned}
& T E=\exp \left(-E\left[u_{i} \mid\left(v_{i}-u_{i}\right)\right]\right) \\
& 0 \leq T E \leq 1
\end{aligned}
$$

Penelitian ini menggunakan data mikro yang berasal dari hasil Sensus Ekonomi 2016 (SE2016) Lanjutan. SE2016-Lanjutan dilaksanakan secara serentak pada bulan AgustusSeptember

di seluruh wilayah Indonesia, termasuk Banten. Jumlah responden UMK Banten yang dikumpulkan dalam SE2016-Lanjutan, sesungguhnya mencapai 51.549 usaha/perusahaan yang tersebar di berbagai sektor ekonomi atau lapangan usaha. Namun, jumlah sampel UMK yang eligible untuk estimasi TE dan determinannya sebanyak 50.042 usaha/perusahan (sebaran sampel UMK terlampir).

Untuk estimasi TE dan determinannya, penelitian ini menggunakan 11 variabel. Empat variabel, yaitu pendapatan usaha sebulan, biaya produksi (pengeluaran usaha non upah/gaji pekerja) sebulan, jumlah tenaga kerja, jam kerja per hari, digunakan untuk estimasi SPF. Adapun untuk estimasi determinan, menggunakan variabel pendidikan (pendidikan pengusaha), lokasi usaha, lama usaha, akses modal, kemitraan usaha, penggunaan internet, dan infrastruktur. Kesebelas variabel tersebut merupakan karakteristik UMK yang datanya dikumpulkan dalam SE2016-Lanjutan.

Tabel 1 memperlihatkan ringkasan statistik untuk 11 variabel yang digunakan dalam penelitian TE dan determinannya. Di antara 5 variabel yang memiliki jenis data rasio, yaitu pendapatan usaha, biaya produksi, jumlah tenaga kerja, dan lama usaha, variabel biaya produksi memiliki keragaman atau variasi yang relatif paling tinggi dengan koefisien variasi mencapai 4,57. Namun demikian, pendapatan usaha UMK secara umum memiliki simpangan yang paling jauh dari nilai rata-ratanya, karena mempunyai simpangan baku paling besar.

Tabel 1. Statistik Deskriptif Variabel TE-SFA UMK Banten

\begin{tabular}{cccc}
\hline Variabel & Rata-rata & $\begin{array}{c}\text { Simpangan } \\
\text { Baku }\end{array}$ & $\begin{array}{c}\text { Koefisien } \\
\text { Variasi }\end{array}$ \\
\hline Pendapatan usaha sebulan (rupiah) & 13.829 .461 & 45.954 .073 & 3,32
\end{tabular}


Jurnal Lebesgue : Jurnal IImiah Pendidikan Matematika, Matematika dan Statistika

Saeful Hidayat, Sadi'ah

Volume 2, No. 1, April 2021 hal.45-61

DOI Artikel : 10.46306/lb.v2i1.55

$\begin{array}{lccc}\text { Biaya produksi (pengeluaran usaha } & 6.015 .675 & 27.479 .369 & 4,57 \\ \text { non upah/gaji pekerja) sebulan } & 2,3323 & 3,7957 & 1,63 \\ \text { Tenaga kerja (orang) } & 9,1946 & 3,7498 & 0,41 \\ \text { Jam kerja per hari (jam) } & 8,600 & 8,385 & 0,98 \\ \text { Lama usaha (tahun) } & 3,138 & - & - \\ \text { Pendidikan } & 0,827 & - & - \\ \text { Lokasi } & 0,078 & - & - \\ \text { Akses modal } & 0,076 & - & - \\ \text { Kemitraan } & 0,077 & - & - \\ \text { Internet } & 0,947 & - & - \\ \text { Infrastruktur } & & & -\end{array}$

Sumber : Hasil SE 2016 Lanjutan (data diolah penulis)

Variabel pendidikan pengusaha UMK memiliki rata-rata 3,138. Berarti, pengusaha UMK kebanyakan adalah lulusan SMA dan Sederajat daripada lulusan SMP. Meskipun demikian, proporsi pengusaha UMK lulusan SMP ke Bawah lebih banyak dibandingkan lulusan SMA ke Atas.

Sementara untuk variabel lokasi usaha, memiliki rata-rata 0,827. Berarti, 82,7 persen UMK yang terpilih dalam penilitian ini berlokasi di wilayah perkotaan. Sisanya. Sebanyak 17,3 persen berlokasi di wilayah perdesaan. Ketersediaan fasilitas infrastrastruktur di daerah perkotaan, jelas lebih baik dibandingkan perdesaan. Imbasnya, hanya 5,3 persen UMK yang memiliki kendala dalam ketersediaan infrastruktur, seperti jalan, air, komunikasi dll.

Selanjutnya, kebanyakan UMK banyak yang tidak memiliki akses permodalan dari lembaga keuangan formal. Kondisi ini kemungkinan dapat menyulitkan mereka dalam upaya mengembangkan usaha. Bukan hanya itu, mereka juga mungkin mengalami kesulitan dalam memenuhi kenaikan pesanan barang/jasa yang diproduksi atau dijual, karena kurangnya modal kerja.

Sementara itu menurut UU No. 20 Tahun 2008 Tentang Usaha Mikro, Kecil dan Menengah, kemitraan adalah kerjasama dalam keterkaitan usaha, baik langsung maupun tidak langsung, atas dasar prinsip saling memerlukan, mempercayai, memperkuat, dan menguntungkan, yang melibatkan pelaku UMKM dengan usaha besar (UB). Dengan demikian, mengikuti program kemitraan akan sangat menguntungkan UMK. Sayangnya, hanya ada 7,6 persen UMK yang mengikuti mengikuti program kemitraan.

Kebanyakan UMK juga tidak memanfaatkan media internet untuk pemasaran dan/atau 
Jurnal Lebesgue : Jurnal Ilmiah Pendidikan Matematika, Matematika dan Statistika

Saeful Hidayat, Sadi'ah

Volume 2, No. 1, April 2021 hal.45-61

DOI Artikel : 10.46306/lb.v2i1.55

transaksi penjualan dan pembelian. Sementara pemasaran via internet dapat menghemat biaya, sekaligus meningkatkan pasar produk. Adapun transaksi penjualan/pembelian melalui internet, akan mempercepat proses transaksi dan menghemat waktu, memudahkan dalam monitoring transaksi, serta dapat meningkatkan profit perusahaan.

\section{HASIL DAN PEMBAHASAN}

Hasil estimasi fungsi produksi frontier stokastik (SPF) yang tertera pada Tabel 2, memperlihatkan bahwa semua parameter dari input produksi secara statistik sangat signifikan. Tanda dari setiap parameter juga seperti yang diharapkan, yaitu positif semua. Biaya produksi berpengaruh positif terhadap pendapatan UMK. Dalam hal ini, meningkatnya jumlah atau jenis barang/jasa yang diproduksi atau diperdagangkan yang direprenstasikan dengan naiknya biaya produksi, akan meningkatkan jumlah pesanan atau permintaan. Implikasinya, pendapatan usaha akan meningkat seiring dengan naiknya jumlah atau jenis barang/jasa yang diproduksi atau diperdagangkan.

Adapun besaran parameter atau elastisitasnya yang mencapai 0,5305, menandakan bahwa untuk setiap satu persen kenaikan biaya produksi, pendapatan UMK akan meningkat 0,53 persen. Besaran elastisitas ini ternyata juga lebih tinggi dibandingkan besaran elastisitas faktor produksi lain, yakni tenaga kerja dan jam kerja per hari. Dengan demikian, kenaikan jumlah atau jenis barang/jasa yang diproduksi atau diperdagangkan yang direpresentasikan dengan biaya produksi, menjadi faktor produksi yang paling dominan dalam meningkatkan pendapatan UMK.

Variabel tenaga kerja terlihat berpengaruh positif terhadap peningkatan pendapatan UMK. Berarti, dengan memperkerjakan lebih banyak tenaga kerja, tingkat produksi barang/jasa yang diinginkan oleh pengusaha akan dapat terpenuhi. Kenaikan jumlah pesanan atau permintaan, juga akan lebih terlayani dengan baik. Imbasnya, pendapatan usaha akan meningkat pula.

Variabel jam kerja per hari berpengaruh positif terhadap pendapatan UMK. Berarti, semakin lama jam kerja atau waktu operasional usaha per hari, semakin tinggi pula pendapatan UMK. Dengan demikian, penambahan jam operasional usaha perlu dilakukan untuk meningkatkan pendapatan usaha. Hanya saja pengaruh penambahannya terhadap kenaikan pendapatan UMK relatif kecil, yakni hanya 0,04 persen untuk setiap satu persen penambahan jam kerja.

Selanjutnya, dengan memperhatikan hasil penjumlahan ketiga besaran paramater dari masing-masing variabel yang melebihi satu, dapat dikatakan bahwa fungsi produksi UMK yang ada di Banten, secara umum bersifat increasing return to scale (IRS). Berarti, proporsi 
Jurnal Lebesgue : Jurnal IImiah Pendidikan Matematika, Matematika dan Statistika

Saeful Hidayat, Sadi'ah

Volume 2, No. 1, April 2021 hal.45-61

DOI Artikel : 10.46306/lb.v2i1.55

penambahan atau peningkatan ouput yang dihasilkan, melebihi proporsi peningkatan pada semua inputnya.

Tabel 2. Hasil Estimasi Parameter SPF dengan Metode TE Effect Model

\begin{tabular}{lccc}
\hline \multicolumn{1}{c}{ Parameter } & Koefisien & Std. Error & Nilai Z \\
\hline Fungsi Produksi : & & & \\
\hline 1. Biaya produksi & $0,5305^{* * *}$ & 0,0021 & 256,05 \\
2. Tenaga kerja & $0,5098^{* * *}$ & 0,0046 & 111,72 \\
3. Jam kerja per hari & $0,0441^{* * *}$ & 0,0053 & 8,35 \\
Konstanta & $7,6795^{* * *}$ & 0,0309 & 248,58 \\
Fungsi Inefisien Teknis (Fungsi U): & & & \\
\hline 1. Pendidikan & $-0,4523^{* * *}$ & 0,0398 & $-11,36$ \\
2. Lokasi & $-1,9615^{* * *}$ & 0,0997 & $-19,68$ \\
3. Lama usaha & $-0,0307^{* * *}$ & 0,0053 & $-5,80$ \\
4. Akses modal & $-0,9013^{* * * *}$ & 0,2041 & $-4,42$ \\
5. Kemitraan & $-1,9226^{* * * *}$ & 0,3924 & $-4,90$ \\
6. Internet & $-2,8107^{* * *}$ & 0,8696 & $-3,23$ \\
7. Infrastruktur & $-0,4932^{* * * *}$ & 0,1053 & $-4,68$ \\
Konstanta & $-0,2615^{* * *}$ & 0,1319 & $-1,98$ \\
Wald chi2 (3) & 123.125 & & \\
Prob > chi2 & 0,0000 & & \\
Jumlah observasi & 50.042 & & \\
\hline
\end{tabular}

Catatan : *** Sangat signifikan pada $\alpha=1 \%$

** Signifikan pada $\alpha=5 \%$

Sumber : Print out Stata SPF-TE Effect Model (data diolah penulis)

\section{Tingkat Efisiensi Teknis}

Hasil pengukuran tingkat efisiensi teknis (TE) UMK Banten dengan metode SFA-TE Effect Model, diperoleh rata-rata sebesar 0,901 dan dengan koefisien variasi yang cukup rendah, yakni 0,08. Angka TE ini termasuk dalam kategori sangat tinggi, karena pendapatan usahanya mencapai 90,1 persen dari frontier. Dengan frontier-nya adalah pendapatan maksimum yang dapat diraih UMK, dengan sistem pengelolaan yang terbaik.

Dalam Gambar 1, disajikan bentuk sebaran UMK menurut tingkat efisiensi yang dicapainya. Terlihat bahwa dari seluruh sampel yang diteliti, lebih dari dua pertiga UMK berada pada selang 0,850- 0,949. Proporsi UMK yang mendekati frontier (TE 1) ada 17,98 persen, 
sedangkan yang berada di bawah 0,750 hanya 5,37 persen.

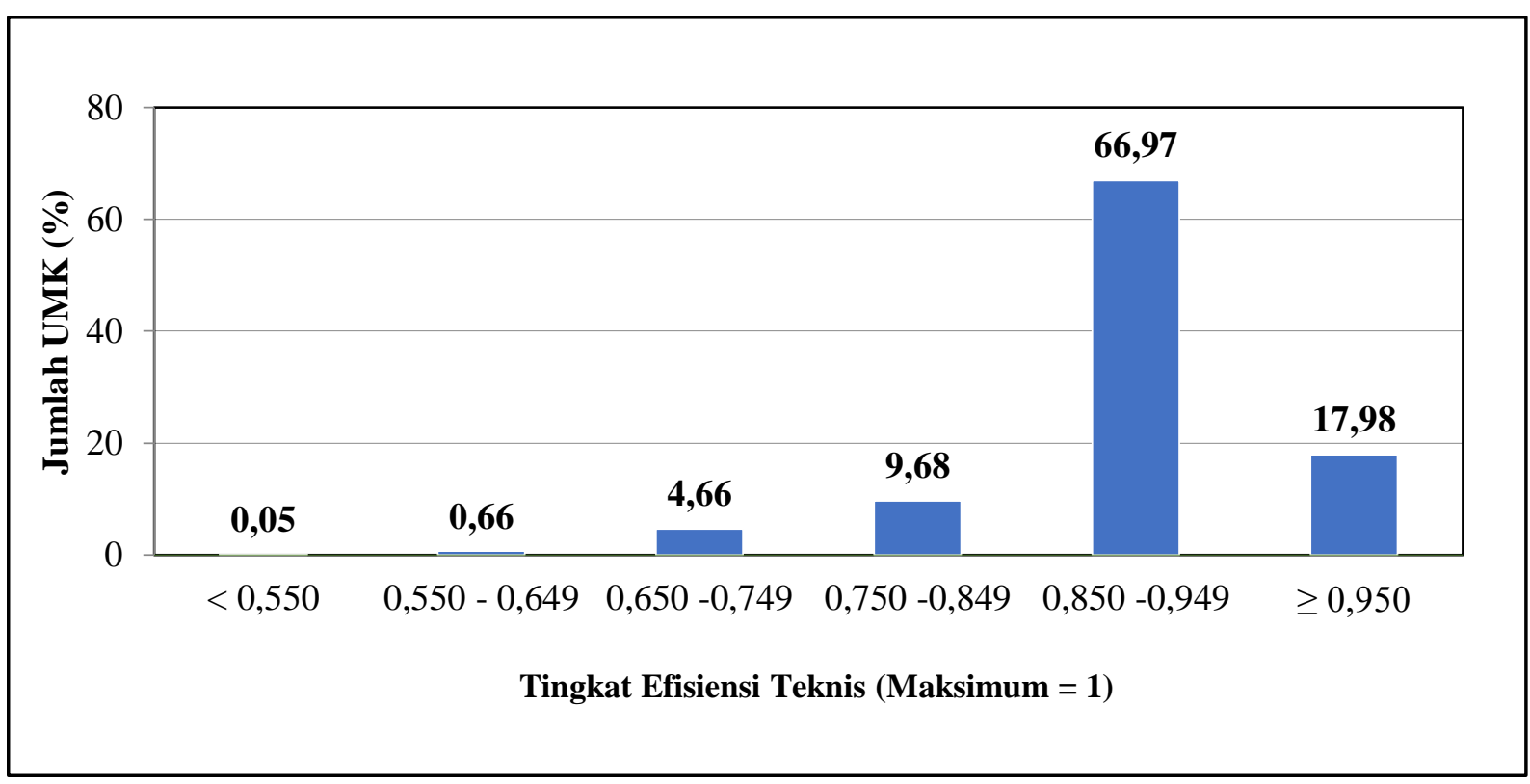

Gambar 1. Sebaran UMK menurut tingkat efisiensi teknis yang dicapai

Sumber : Hasil estimasi TE pada data SE2016-Lanjutan dengan metode SPF-TE Effect Model (data diolah penulis)

Sayangnya, tingkat efisiensi yang tinggi juga merefleksikan peluang untuk meningkatkan kinerja usaha menjadi semakin kecil. Hal ini karena selisih antara tingkat pendapatan yang telah dicapai dengan pendapatan maksimal yang dapat diraih, sudah cukup sempit. Dengan kata lain, dibutuhkan inovasi dan penggunaan teknologi yang lebih maju agar kinerja usaha semakin meningkat.

Betapapun juga, peningkatan kinerja usaha masih dapat dilakukan terhadap UMK yang memiliki TE cukup rendah. Bila diasumsikan TE yang rendah adalah yang bernilai di bawah 0,750, maka upaya peningkatan kinerja usaha dapat difokuskan kepada UMK yang memiliki TE kurang dari 0,75. Dalam hal ini, terdapat 5,37 persen UMK yang memiliki TE di bawah 0,75 (Gambar 1).

Diamati menurut skala dan lapangan usaha (Tabel 3), rata-rata TE usaha mikro dalam berbagai lapangan usaha selalu lebih rendah dibandingkan usaha kecil. Untuk usaha berskala mikro, TE tertinggi dimiliki lapangan usaha pengadaan listrik dan gas. Lapangan usaha jasa pendidikan, memiliki TE tertinggi untuk kelompok usaha berskala kecil. Sementara pertambangan dan penggalian menjadi lapangan usaha yang memiliki rata-rata TE terendah, 
Jurnal Lebesgue : Jurnal IImiah Pendidikan Matematika, Matematika dan Statistika

Saeful Hidayat, Sadi'ah

Volume 2, No. 1, April 2021 hal.45-61

DOI Artikel : 10.46306/lb.v2i1.55

baik untuk usaha mikro maupun usaha kecil. Adapun secara keseluruhan, TE UMK tertinggi juga dipegang oleh lapangan usaha pengadaan listrik dan gas.

Tabel 3. Rata-rata Tingkat Efisiensi Teknis Menurut Kategori Lapangan Usaha dan Skala Usaha

\begin{tabular}{lccc}
\hline \multicolumn{1}{c}{ Lapangan Usaha } & \multicolumn{3}{c}{ Skala Usaha } \\
\cline { 2 - 4 } & $\begin{array}{c}\text { Mikro } \\
\text { (UM) }\end{array}$ & $\begin{array}{c}\text { Kecil } \\
\text { (UK) }\end{array}$ & $\begin{array}{c}\text { Mikro+Kecil } \\
\text { (UMK) }\end{array}$ \\
\hline B. Pertambangan dan Penggalian & 0,767 & 0,808 & 0,769 \\
C. Industri Pengolahan & 0,884 & 0,926 & 0,891 \\
D. Pengadaan Listrik dan Gas & 0,945 & 0,967 & 0,949 \\
E. Pengadaan Air, Pengelolaan Sampah, & 0,881 & 0,934 & 0,890 \\
$\quad$ Limbah dan Daur Ulang & 0,906 & 0,962 & 0,912 \\
F. Konstruksi & 0,893 & 0,927 & 0,897 \\
G. Perdagangan Besar-Eceran dan Reparasi & 0,885 & 0,946 & 0,886 \\
$\quad$ Mobil-Sepeda Motor & 0,893 & 0,929 & 0,897 \\
H. Transportasi dan Pergudangan & 0,921 & 0,959 & 0,924 \\
I. Penyediaan Akomodasi dan Makan Minum & 0,940 & 0,955 & 0,947 \\
J. Informasi dan Komunikasi & 0,915 & 0,938 & 0,915 \\
K. Jasa Keuangan dan Asuransi & 0,926 & 0,962 & 0,934 \\
L. Real Estat & 0,925 & 0,972 & 0,937 \\
M,N. Jasa Perusahaan & 0,932 & 0,965 & 0,939 \\
P. Jasa Pendidikan & 0,910 & 0,952 & 0,913 \\
Q. Jasa Kesehatan dan Kegiatan Sosial & 0,896 & 0,936 & 0,901 \\
R,S. Jasa Lainnya & & & \\
\hline Total & & 0,969 \\
\hline
\end{tabular}

Sumber : Hasil estimasi TE pada data SE 2016-Lanjutan dengan metode SPF-TE Effect Model (data diolah penulis)

UMK Banten yang bergerak dalam lapangan usaha industri pengolahan memiliki rata-rata TE yang cukup tinggi, yakni mencapai 0,891. Angka TE ini ternyata juga lebih tinggi dibandingkan TE UMK Indonesia 2010-2015, yang rata-rata hanya 0,504. Angka TE Indonesia tersebut dihitung dari data hasil survei tahunan industri mikro kecil (IMK) BPS, dengan metode DEA dan menggunakan variabel pendapatan, biaya produksi, jumlah tenaga kerja. dan aset tetap untuk mengukur frontier-nya (Setiawan dkk, 2019).

Lapangan usaha jasa keuangan dan asuransi memiliki rata-rata TE yang sangat tinggi. Namun demikian, angka TE UMK ini masih berada di bawah TE UMB dalam lapangan usaha jasa keuangan dan asuransi di Indonesia. Dalam hal ini, lebih rendah dari TE bank pemerintah, (1) 55 
Jurnal Lebesgue : Jurnal IImiah Pendidikan Matematika, Matematika dan Statistika

Saeful Hidayat, Sadi'ah

Volume 2, No. 1, April 2021 hal.45-61

DOI Artikel : 10.46306/lb.v2i1.55

bank pembangunan daerah, dan bank swasta nasional devisa yang masing-masing mencapai 0,995, 1,000, dan 0,944, yang dihitung dengan menggunakan metode DEA (Marsondang dkk, 2019).

Bila diperhatikan menurut kabupaten/kota tempat usaha (Gambar 2), terlihat bahwa TE UMK tertinggi terdapat di wilayah Tangerang Raya, yaitu Kota Tangerang Selatan, Kota Tangerang dan Kabupaten Tangerang. Ketiga kabupaten/kota ini masing-masing memiliki ratarata TE sebesar 0,$932 ; 0,928$; dan 0,925 . Sementara TE terendah untuk UMK yang berlokasi di Kabupaten Lebak dan Kabupaten Pandeglang, yakni hanya mencapai 0,832 dan 0,864.

Dengan demikian, urutan besaran TE UMK di Banten sepertinya sudah sesuai dengan gambaran kemajuan daerah. Banyak faktor yang menjadi penyebab, mengapa kondisi tersebut dapat terjadi. Untuk lebih jelasnya, dapat dilihat pada bagian faktor-faktor yang mempengaruhi efisiensi teknis UMK di bawah ini.

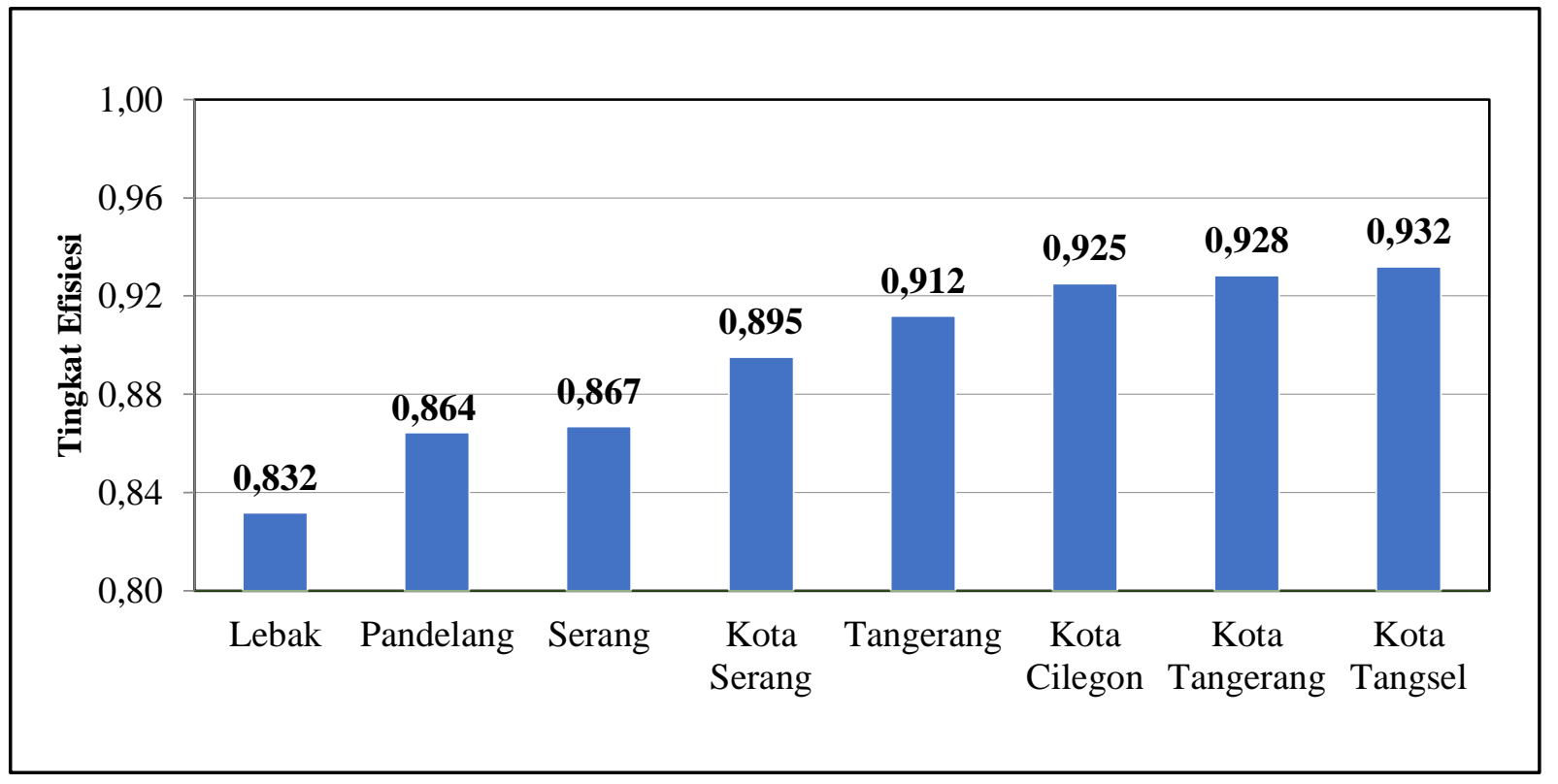

Gambar 2. Rata-rata tingkat ffisien teknis UMK menurut kabupaten/kota

Sumber : Hasil estimasi TE pada data SE2016-Lanjutan dengan metode SPF-TE Effect Model (data diolah penulis)

\section{Faktor-fakor yang Mempengaruhi Efisiensi Teknis UMK}

Fungsi inefisiensi teknis yang estimasi parameternya disampaikan pada Tabel 1, merupakan fungsi yang menggambarkan determinan inefisiensi teknis UMK. Ada tujuh variabel atau faktor yang dihipotesakan dapat menjadi deteminan inefisiensi teknis UMK, yaitu tingkat pendidikan pengusaha, lokasi usaha, lama usaha, akses modal, kemitraan usaha, 
internet, dan infrastruktur. Namun, karena semua parameternya mempunyai tanda negatif atau berkorelasi negatif dengan inefisiensi teknis, ketujuh faktor ini justru menjadi determinan bagi efiesien teknis UMK.

Ketujuh faktor tersebut di atas, ternyata juga memiliki peran atau pengaruh yang signifikan terhadap peningkatan efisiensi teknis UMK. Adapun besarnya peranan setiap faktor, tercermin pada besaran parameternya. Dengan demikian, faktor terpenting dalam menaikkan efisiensi teknis UMK di Banten adalah internet, lokasi usaha dan kemitraan usaha.

Teknologi informasi, dalam hal ini penggunaan internet memang berperan penting dalam meningkatkan kinerja dan daya saing UMK. Beberapa manfaat yang didapatkan UMK bila menggunakan internet, antara lain mempermudah komunikasi dengan pemasok dan konsumen. Selain itu, ada kemudahan dalam mempromosikan produk barang/jasa atau memperluas jaringan pemasaran dan bahkan, memperbesar market share. Terakhir, kemudahan dalam melakukan transaksi pembelian dari pemasok maupun penjualan barang/jasa kepada konsumen. Semua kemudahan ini dapat diperoleh dengan biaya yang relatif rendah dan dengan potensi keuntungan yang berlipat. Dengan demikian, UMK yang menggunakan internet untuk pemasaran dan penjualan/pembelian mempunyai tingkat efisiensi lebih tinggi daripada UMK yang sama sekali tidak menggunakan atau memanfaatkan internet untuk keperluan selain pemasaran dan penjualan/pembelian.

Pemilihan lokasi usaha yang strategis menjadi salah satu faktor yang mempengaruhi kesuksesan usaha. Lokasi usaha yang strategis tidak hanya dilihat dari sisi pemasaran saja, tapi juga dari kemudahan dalam memperoleh bahan baku atau barang dagangan. Dibandingkan di daerah perdesaan, UMK di daerah perkotaan pada umumnya memiliki keunggulan berupa kemudahan dalam memperoleh bahan baku atau barang dagangan, serta ketersediaan pasar yang lebih luas. Imbasnya, UMK di daerah perkotaan memiliki biaya produksi relatif lebih rendah dan pendapatan yang relatif tinggi dari UMK yang berlokasi di daerah perdesaan. Oleh karena itu, UMK yang berlokasi di daerah perkotaan akan lebih efisien dibandingkan yang beroperasi di perdesaan. Hasil ini mengkonfirmasi penelitian yang dilakukan oleh Tunggal dan Joesron (2019) pada UMi ISIC 14 serta UMi dan UK ISIC 16.

Kemitraan menurut UU No. 20 Tahun 2008 Tentang Usaha Mikro, Kecil dan Menengah, mencakup proses alih keterampilan di bidang produksi dan pengolahan, pemasaran, permodalan, sumber daya manusia, dan teknologi. Berarti, dengan mengikuti program kemitraan terutama dengan UMB, UMK akan mendapatkan bimbingan dan pelatihan teknis terkait hal tersebut di atas. Pelaku UMK kemungkinan juga dapat memperoleh bantuan atau 
tambahan permodalan bagi usaha yang dilakukannya. Dengan demikian, UMK yang memiliki kemitraan dengan perusahaan lain (UMB), memiliki tingkat efisiensi yang lebih tinggi daripada UMK yang tidak mengikuti kemitraan. Hasil ini memang berlawanan dengan penelitian Fauziah dkk (2020). Namun, ada kemungkinan kondisi tersebut dipengaruhi oleh besaran data yang diolah Fauziah dkk (2020), yang hanya sebanyak 2.550 usaha. Selain itu ada perbedaan cakupan antara kedua penelitian ini dengan penelitian Fauziah dkk (2020).

Ketersediaan dana yang mencukupi sangat penting bagi pelaku UMK. Dengan dana yang mencukupi, UMK bisa mengembangkan usaha agar dapat naik kelas menjadi UK. Jika tidak mencukupi untuk pengembangan usaha, dana tersebut bisa digunakan untuk memenuhi kenaikan jumlah pesanan atau permintaan konsumen. Dengan jumlah pesanan yang meningkat, pembelian bahan baku atau barang dagangan dapat dilakukan dengan lebih banyak dan lebih murah, sehingga terjadi efisiensi biaya dan maksimisasi keuntungan.

Bila sama sekali tidak memiliki dana, kebutuhan dana investasi dan kekurangan modal kerja dapat dibiayai melalui pinjaman. Peminjaman dapat dilakukan, jika pelaku UMK memiliki akses permodalan, terutama dari terutama lembaga keuangan formal. Kondisi inilah yang membuat UMK dengan akses permodalan dari lembaga keuangan formal, memiliki tingkat efisiensi yang lebih tingg dibandingkan UMK yang tidak memilikinya. Dengan demikian, hasil penelitian ini mengkonfirmasi penelitian yang dilakukan oleh Tunggal dan Joesron (2019) pada UMi ISIC 14.

Fasilitas infrastruktur (jalan, air, komunikasi dll) merupakan instrumen penting yang mendorong berputarnya aktivitas ekonomi di suatu wilayah. Dalam hal ini, ketersediaan infrastruktur akan memudahkan mobilitas faktor produksi (tenaga kerja), memperlancar arus barang dan jasa karena biaya pengangkutan menurun, dan meningkatkan perdagangan antar daerah. Dalam konteks UMK, ketersediaan infrastruktur akan menurunkan ongkos angkut dan biaya produksi serta meningkatkan pendapatan usaha. Oleh sebab itu, UMK yang tidak terkendala infrastruktur (jalan, air, komunikasi dll) mempunyai efisiensi yang lebih tinggi daripada UMK yang memiliki kendala infrastruktur.

Sementara itu pendidikan yang lebih tinggi dapat memperluas cakrawala ilmu dan pengetahuan seorang individu. Melalui ilmu dan pengetahuan ini, terbentuk nilai, sikap, perilaku, dan rasionalitas pemikiran yang digunakannya dalam kehidupan sehari-hari. Ketika menjadi pelaku UMK, individu tersebut akan lebih memungkinkan untuk bertindak atau mengambil keputusan secara lebih rasional dibandingkan mereka yang memiliki pendidikan lebih rendah. Oleh sebab itu, tidak mengherankan bila tingkat pendidikan pengusaha 
Jurnal Lebesgue : Jurnal IImiah Pendidikan Matematika, Matematika dan Statistika

Saeful Hidayat, Sadi'ah

Volume 2, No. 1, April 2021 hal.45-61

DOI Artikel : 10.46306/lb.v2i1.55

mempunyai pengaruh positif terhadap efisiensi teknis UMK. Hasil ini mengkonfirmasi pengaruh positif pendidikan pengusaha terhadap efisiensi teknis UMK industri pengolahan yang dihasilkan oleh Setiawan dkk (2019).

Variabel lama berusaha berkaitan erat dengan pengalaman, relasi usaha dan pelanggan setia. Pengalaman mendorong pengusaha untuk memiliki kemampuan manajerial yang lebih baik dan penguasaan teknis produksi yang lebih efisien. Relasi usaha membuat pengusaha dapat memperoleh bahan baku atau barang dagangan dengan biaya yang lebih murah, serta kemungkinan perluasan pasar. Adapun pelanggan setia, setidaknya dapat menghemat biaya iklan atau pemasaran. Oleh karena itu, dapat dipahami bila UMK yang telah lama berusaha akan memiliki efisiensi lebih tinggi. Dengan demikian, hasil penelitian ini berlawanan dengan Setiawan dkk (2019), namun bersesuaian dengan penelitian Tunggal dan Joesron (2019) pada UMi ISIC 10.

Menurut Pitt dan Lee (1981) dalam Gomez dkk (2018), hubungan negatif antara lama usaha dengan TE dapat terjadi karena perusahaan yang berusia lebih muda memiliki infrastruktur usaha yang lebih modern dan teknologi yang maju. Selain itu, Batra dan Tan (2003) dalam Gomez dkk (2018), juga menyatakan bahwa manfaat dari akumulasi pengetahuan yang dimiliki oleh perusahaan yang berusia lebih mudah, tidak dapat ditutupi oleh tingginya biaya produksi karena menggunakan infrastruktur fisik dan teknologi yang ketinggalan jaman.

\section{KESIMPULAN}

Rata-rata tingkat efisiensi teknis (TE) yang dicapai UMK di Banten sangat tinggi, yaitu mencapai 0,901. Determinan utama efisiensi teknis UMK-nya adalah penggunaan internet, lokasi usaha dan kemitraan. Tingkat efisiensi yang lebih tinggi dicapai oleh UMK yang menggunakan internet untuk pemasaran dan transkasi penjualan/pembelian, berlokasi di daerah perkotaan, dan memiliki kemitraan dengan UMB. Faktor lain yang mendorong kenaikan efisiensi teknis UMK adalah akses modal dari lembaga keuangan formal dan ketersedian infrastruktur (jalan, air, komunikasi dll). Hasil penelitian ini juga menunjukkan bahwa efisiensi teknis UMK yang lebih tinggi dimiliki pelaku UMK berpendidikan tinggi dan UMK yang sudah lebih lama berusaha.

Implikasi terpenting dari hasil penelitian ini adalah perlunya kebijakan yang mampu mendorong peningkatan penggunaan internet untuk usaha di kalangan pelaku UMK. Dalam konteks ini, Pemerintah wajib mengadakan pelatihan yang aplikatif terkait internet marketing, online shop dan marketplace kepada pelaku UMK. Selain itu, Pemerintah juga perlu membebaskan/memberikan potongan biaya kuota internet secara sementara pada tahap-tahap 
Jurnal Lebesgue : Jurnal IImiah Pendidikan Matematika, Matematika dan Statistika

Saeful Hidayat, Sadi'ah

Volume 2, No. 1, April 2021 hal.45-61

DOI Artikel : 10.46306/lb.v2i1.55

awal UMK menggunakan internet, guna meringankan biaya produksi.

Pemerintah perlu menggalakkan kembali program kemitraan antara UMK dan UMB. Cakupan program kemitraan, juga harus diperluas ke berbagai sektor ekonomi atau bidang usaha. Dengan demikian, akan semakin banyak lagi UMK yang terlibat dan mengambil manfaat dari keikutsertaannya dalam program kemitraan.

Khusus akses modal, Pemerintah Provinsi Banten perlu mencontoh Pemerintah Provinsi Jawa Tengah yang menyediakan dana murah kepada warganya untuk memulai atau mengembangkan usaha. Dalam hal ini, Bank Jawa Tengah memiliki Fasilitas Kredit Mitra $\begin{array}{llll}\text { Jateng } & \text { maksimal } & \text { juta }\end{array}$ (KMJ 25) bagi usaha mikro kecil, yang bebas biaya administrasi, biaya provisi dan tanpa agunan fisik, dengan bunga 7 persen per tahun efektif (tahun 2020 turun menjadi 6 persen). Persyaratannya juga sangat mudah, yakni cukup dengan menyertakan FC KTP dan Kartu KK serta menunjukkan usaha yang baru mulai atau sudah berjalan, tentunya disertai pengesahan dari Kepala Desa/Lurah atau Dinas Pasar bila lokasi usahanya di pasar.

\section{DAFTAR PUSTAKA}

Adnyani, L. P. W., \& Sihombing, P. R. (2021). ANALISIS CLUSTER TIME SERIES DALAM PENGELOMPOKAN PROVINSI DI INDONESIA BERDASARKAN NILAI PDRB. Jurnal Bayesian: Jurnal Ilmiah Statistika dan Ekonometrika, 1(1), 47-54.

Aigner, D., Lovell, C.A.K., and Schmidt, P. 1977. Formulation and Estimation of Stochastic Frontier Production Function Models: Journal of Econometrics: Vol. 6, Issue 1, hlm 2137.

Battese, G.E. and Coelli, T.J. 1995. A Model For Techincal Inefficiency in a Stochastic Frontier Production for Panel Data: Empirical Economic: Vol. 20, hlm 325 - 332.

BPS Provinsi Banten. 2019. Hasil Pendataan Usaha/Perusahaan Sensus Ekonomi 2016. Kota Serang: BPS Provinsi Banten.

BPS Provinsi Banten. 2020a. Analisis Hasil Survei Dampak Covid-19 Terhadap Pelaku Usaha. Kota Serang : BPS Provinsi Banten.

BPS Provinsi Banten. 2020b. Laporan Eksekutif Keadaan Angkatan Kerja Provinsi Banten Agustus 2020. Kota Serang : BPS Provinsi Banten.

Charnes, A., Cooper, W., and Rhodes, E. 1978. Measuring the Efficiency of Decision Making Units: European Journal of Operation Research: Vol. 2, Issue 6, hlm 429-444.

Coelli, T.J. 1996a. A Guide to DEAP Version 4.1: A Data Envelopment Analysis (Computer) Program. New South Wales : Centre for Efficiency and Productivity Analysis, University of New England - Armidale.

Coelli, T.J. 1996b. A Guide to Frontier Version 4.1: A Computer Program for Stochastic Frontier Production and Cost Function Estimation. New South Wales : Centre for Efficiency and Productivity Analysis. University of New England - Armidale.

Coelli T.J. Rao, D.S.P., O’Donnell, C.J., and Battese G.E. 2005. An Introduction to Efficiency and Productivity Analysis. New York : Spring Science And Business Media. 
Jurnal Lebesgue : Jurnal IImiah Pendidikan Matematika, Matematika dan Statistika

Saeful Hidayat, Sadi'ah

Volume 2, No. 1, April 2021 hal.45-61

DOI Artikel : 10.46306/lb.v2i1.55

Farrell, M.J., 1957. The measurement of Productive Efficiency: Journal of the Royal Statistical Society: Series A (General), Vol. 120, Part III, hlm 253-281.

Fariz. 2017. Buku Ajar STIE YAPAN: Pengantar Manajemen. Surabaya : LPPM STIE YAPAN.

Gomez, P.P., Perez, M.A., and Arbelo, A. 2018. Profit Efficiency and Its Determinants in Small and Medium-sized Enterprises in Spain: BRQ Business Research Quarterly: Vol. 21, Issue 4, hlm 238-250.

Kontodimopoulos, Nick., Papathanasiou, N.D., Flokou, A., Tountas, Y., and Niakas, D. 2011. The Impact of Non-Discretionary Factors on DEA and SFA Technical Efficiency Differences: Journal of Medical System: Vol. 35, hlm 981-989.

Kumbhakar, S. C., and Love 11, C. A. K. 2000. The estimation of technical efficiency, In: Stochastic frontier analysis (hlm 63-130). Cambridge : Cambridge University Press. 